\title{
A Study of Zn-Ferrite Core Planar Power Inductor Embedded in Organic Interposer for Power Supply integrated in LSI Package
}

\author{
H. Kobayashi, F. Sato, K. Hagita, R. Takeda*, M. Sonehara, T. Sato, \\ N. Matsushita*, K. Kobayashi**, H. Shimizu**, T. Fujii ${ }^{* *}$, K. Ishida*** and T. Sakurai*** \\ Spin Device Technology Center, Shinshu University, 4-17-1 Wakasato, Nagano 380-8553, Japan \\ *Materials and Structures Laboratory, Tokyo Institute of Technology, 4259 Nagatsuta-cho, Midori-ku, Yokohama 226-8503, Japan \\ **Shinko Electric Industries Co., Ltd., 36 Kita Owaribe, Nagano 381-0014, Japan \\ ***Institute of Industrial Science, The University of Tokyo, 4-6-1 Komaba, Meguro-ku, Tokyo, 153-8505, Japan
}

\begin{abstract}
In order to establish the basic technology of package level DC power grid for next generation power delivery to LSIs, $\mathrm{Zn}$-ferrite core planar power inductor embedded in an organic interposer, for power supply integrated in LSI package, has been fabricated and evaluated. Zn-ferrite core planar power inductor embedded in organic interposer had a footprint of $850 \times 850 \mu \mathrm{m}^{2}$, 2-turn, $20 \mu \mathrm{m}$ thick copper spiral coil sandwiched by top and bottom $\mathrm{Zn}$-ferrite film magnetic core. For a comparison, a 3-turn air core spiral inductor was also embedded in the same organic interposer, which exhibited a large degradation of inductance at high frequencies because of eddy current induced by widespread high frequency magnetic flux passing through the lower layer $\mathrm{Cu}$ metal plane. Zn-ferrite core planar inductor had a relative small decrease of inductance at high frequencies. From 3D electromagnetic field analysis, it was found that the magnetic core inductor embedded in interposer has a great advantage of a possible three dimensional layout of the inductor with small influence on the near signal-line and circuit ground.
\end{abstract}

Key words: Embedded power inductor in LSI package, organic interposer, planar power inductor, Zn-ferrite film, DC-DC converter

\section{LSI パッケージ集積化電源用 Zn フェライト磁心プレーナパワーインダクタの 有機インターポーザへの内蔵に関する検討}

\author{
小林洸貴・佐藤史宏・萩田和洋・武田理恵*・曾根原誠・佐藤敏郎 \\ 松下伸広 $*$. 小林和貴 $* *$ 清水浩 $* *$ 藤井朋治 $* *$ 石田光一 $* * * \cdot$ 桜井貴康 $* * *$ \\ 信州大学スピンデバイステクノロジーセンター，長野市若里 4-17-1 (テ 380-8553)

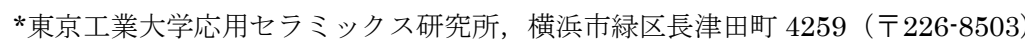 \\ **新光電気工業株式会社，長野市北尾張部 36 († $381-0014)$ \\ ***東京大学生産技術研究所，東京都目黒区駒場 4-6-1(广153-8505)
}

\section{1. はじめに}

近年, LSI の低電圧化が進み, 集積度の向上や高速化に ともなって LSI の消費電流は増大の一途を辿っている.

Fig. 1 に LSI ののパワーデリバリー方式の変遷図を示す. 現在のボードレベル DC パワーグリッドでは，電源－LSI 間の配線損失を低減するため DC-DC コンバータを LSI 近 傍に配置する POL（Point of Load）方式が主流となってい る.

LSI へのパワーデリバリーの究極は，LSI にオンチップ インダクタを搭載し, POL コンバータを集積したチップレ ベル DC パワーグリッドを実現することであり，オンチッ プ磁性薄膜インダクタの試作など 1) -3)，基盤技術の開発が 活発化している，その前段階として，空心インダクタと高 速 CMOS スイッチを組み合わせた集積化 DC-DC コンバー 夕の開発が進められている4), 5)。例えば， INTEL の P. Hazucha らは LSI パッケージ上に表面実装タイプの空心 チップインダクタを 4 個配置した $233 \mathrm{MHz}$ スイッチング
四相 90nm-CMOS スイッチ DC-DC コンバータを試作した 4).また，K. Ishida らはシリコンインターポーザ上に実装 した空心スパイラルインダクタを用いた CMOS スイッチ 降圧 DC-DC コンバータを報告している 5). 空心インダク 夕は導体配線のみで構成できるため作製も容易でコスト的 にも有利であるが，単位面積あたりのインダクタンスが小 さいため素子サイズを小さくすることが難しく，また，空 心インダクタから発生する高周波漏洩磁束は近傍配線にク ロストークノイズを発生させるだけではなく，回路のグラ ンドとして利用される導体プレーンが近傍にある場合に は，うず電流によってインダクタンスが低下すると予測さ れる。

筆者らは，オンチップインダクタを搭載したチップレベ ル DCパワーグリッドの前に, 複数のアプリケーション LSI に直流電力を供給する POL コンバータが同一パッケージ に集積されたパッケージレベル DC パワーグリッドが次世 代の LSI パワーデリバリー方式として実用化されると予測 している。この方式を実現するためには，DC-DCコンバー 


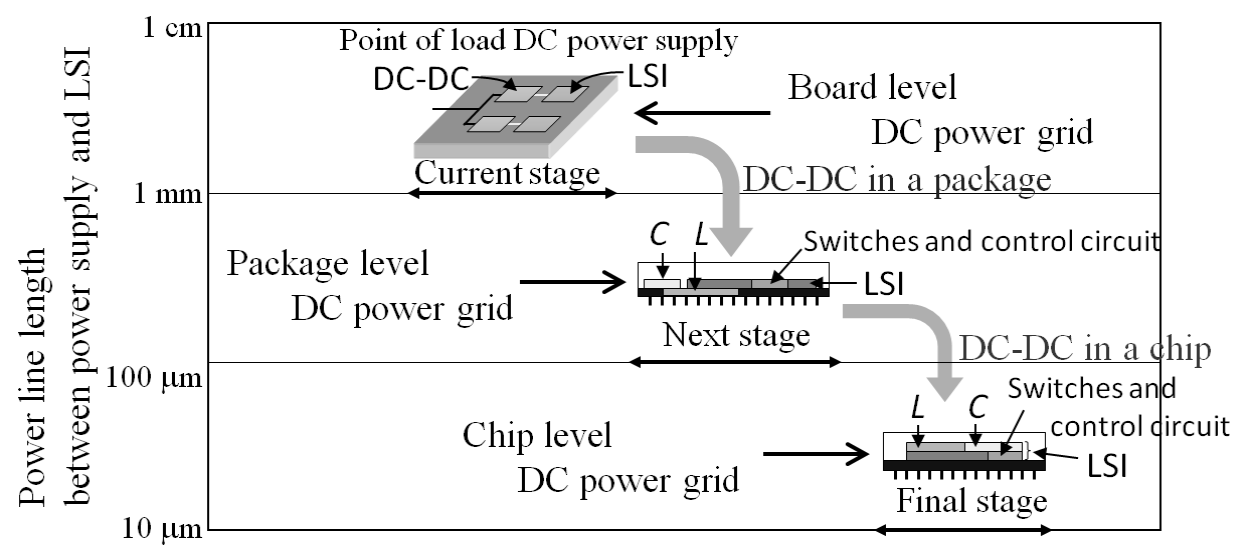

Fig. 1 Trend in power delivery to LSIs.

タの中で最も体積の大きいパワーインダクタの小型化・低 背化が必須であるとともに，複数のパワーインダクタをパ ッケージに内蔵することが必要になる.

筆者らはこれまでに，パワーインダクタの小型・低背化 を目的として，スピンスプレー法によるスピネルフェライ 卜膜作製技術 6), 7)を用いた $\mathrm{Zn}$ フェライト厚膜磁心やスクリ ーン印刷法による金属磁性微粒子複合材料磁心を採用した プレーナパワーインダクタを試作し 8), 9), 数十 $\mathrm{MHz}$ 数百 $\mathrm{MHz}$ のスイッチング周波数で動作する数 $\mathrm{W}$ 出力の $\mathrm{CMOS}$ スイッチ DC-DC コンバータに適用可能であることを示し た。しかしながら，これまでの試作インダクタはガラス基 板上に作製されたものであり，パッケージレベル DC パワ ーグリッドを実現するためにはパッケージへのインダクタ 内蔵などの基盤技術を確立する必要がある.

本研究は, LSI パッケージ集積化 POL コンバータの基盤 技術として，パワーインダクタのパッケージ内蔵について 検討したものである．本論文では，LSI パッケージにガラ スフィラー有機インターポーザを用い，プレーナインダク タをインターポーザに内蔵する際の諸課題を明らかにする とともに, 内蔵インダクタに磁心材料を用いた場合の効果 を電気特性の測定結果ならびに電磁界解析を用いて空心イ ンダクタの場合と比較した結果を述べる。

\section{2.インダクタ内蔵用有機インターポーザ}

インダクタを内蔵する LSI パッケージには, 現在, 民生 用に多用されている有機インターポーザを採用した.

Fig. 2 は有機インターポーザ基板の断面構造とインダク 夕内蔵の様子を模式的に示したものである. 内蔵インダク タは磁気シールド特性に優れる外鉄磁心内部コイル型 10)プ レーナインダクタと空心インダクタの二種類を検討した.

有機インターポーザ基板はガラス䋊維／エポキシ樹脂か らなる厚さ $800 \mu \mathrm{m}$ のセンターコア層を持ち, その両側を

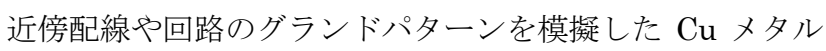
プレーン, ガラスフィラーノエポキシ樹脂からなるビルド アップ層の順に積層した構成となっている. ビルドアップ

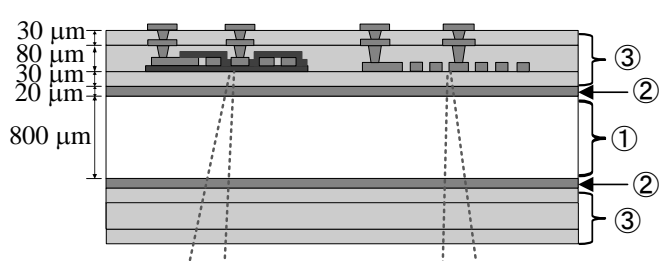

(1)Glass/epoxy core, (2)Metal plane

(3)Build-up layer
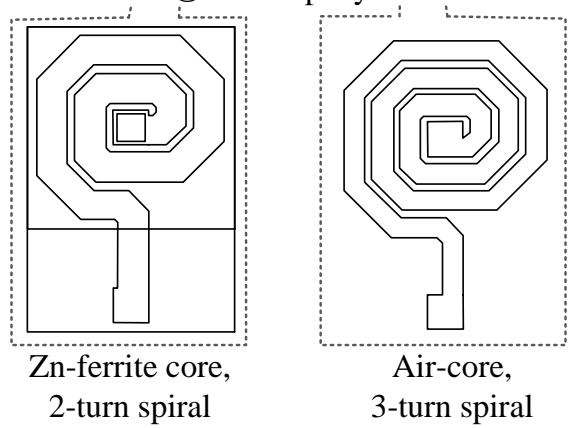

Fig. 2 Schematic cross-sectional view of the organic interposer having embedded inductors in the build-up layer.

層はエポキシ樹脂中に数 $\mu \mathrm{m}$ サイズのガラスフィラーを分 散させた複合材料シートを加圧・加熱して作製されるので, ビルドアップ層の積層工程の途中にインダクタ作製プロセ スを導入することでインターポーザにインダクタを内蔵で きる、エポキシ樹脂を含む有機インターポーザの長時間耐 熱温度は $200^{\circ} \mathrm{C}$ 以下であるため, 内蔵インダクタの作製プ ロセス最高温度はそれ以下にしなければならない。本研究 では， $100^{\circ} \mathrm{C}$ 以下低温溶液プロセスで作製できるスピン スプレー法 $\mathrm{Zn}$ フェライトを内蔵インダクタの外鉄磁心に 採用した。

ビルドアップ層の積層工程の途中にインダクタ作製プロ セスを導入する際，インダクタ作製後にインダクタの凹凸 を吸収して平坦化するため，インダクタの高さ寸法を超え る厚さのビルドアップ層が必要である。これまで試作した Zn フェライト磁心プレーナインダクタ 8), 9)の高さ寸法 50 $\mu \mathrm{m}$ を参考に, インダクタを形成する層のビルドアップ層 の厚さを $80 \mu \mathrm{m}$ とした。 


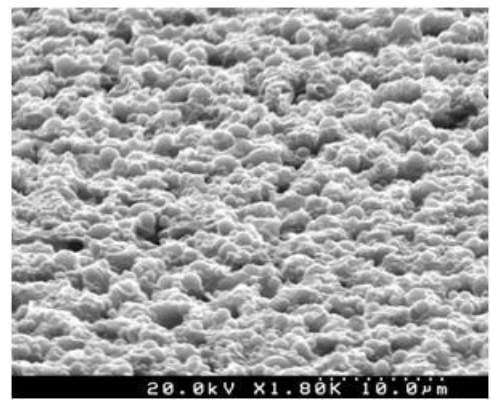

Fig. 3 SEM image of build-up layer surface of the organic interposer, the build-up layer consists of a few $\mu \mathrm{m}$ diameter glass-filler and epoxy resin.

\section{3. 有機インターポーザ内ビルドアップ層に直接成膜した スピンスプレー法 Zn フェライト厚膜の諸特性}

\section{1 ビルドアップ層の表面凹凸}

Fig. 2 で示したように，有機インターポーザに内蔵され る外鉄磁心型プレーナインダクタの下部磁心はビルドアッ プ層を下地として形成される。

Fig. 3 はビルドアップ層の表面 SEM 写真を示したもの である。ビルドアップ層はエポキシ樹脂中に体積比率で約 $50 \%$ \%ガラスフィラーが充填され，Fig. 3 から了解される ように，その表面にはガラスフィラーの粒径に相当する数 $\mu \mathrm{m}$ の凹凸が観察される。

\section{2 ビルドアップ層への $\mathrm{Zn}$ フェライト厚膜の成膜}

$\mathrm{Zn}$ フェライト厚膜はスピンスプレー法 6 (6), 7)にってビル ドアップ層表面に目標膜厚 $10 \mu \mathrm{m}$ で直接成膜した. Zn フ エライト厚膜の組成は $\mathrm{Zn}_{0.22} \mathrm{Fe}_{2.78} \mathrm{O}_{4}$ である.また，ガラス 基板上に形成したポリイミド膜を下地層として成膜した $\mathrm{Zn}$ フェライト厚膜を比較試料として用意した.

\section{3 ビルドアップ層上 $\mathrm{Zn}$ フェライト厚膜の構造と諸特性}

Fig. 4 は，インターポーザ基板のビルドアップ層に Zn フェライト厚膜を直接成膜した場合と，ポリイミド／ガラ ス基板に成膜した場合の断面 SEM 写真を示したものであ る. $\mathrm{X}$ 線回折の結果を併せて検討した結果, 平坦なポリイ ミド表面に成膜された Zn フェライト膜は(111)面優先配向 した柱状結晶粒構造を持っているのに対し，数 $\mu \mathrm{m}$ の凹凸 があるビルドアップ層表面に成膜された $\mathrm{Zn}$ フェライト膜 では結晶粒の成長に方向の規則性が見られず，X 線回折の 結果からも特定の面の結晶配向は観察されなかった.

Fig. 5 に, 振動試料型磁力計（VSM，理研電子(侏): BHV-55）を用いて测定した Zn フェライト厚膜の静磁化特 性を示す，インターポーザ基板のビルドアップ層に直接成 膜された Zn フェライトはポリイミドに成膜された場合に 比べて磁化曲線の磁界に対する傾きが小さく, 保磁力も大 きい.

Fig. 6 は透磁率測定装置（凌和電子(株：PMM-9G1）を 用いて測定した $\mathrm{Zn}$ フェライト厚膜の複素比透磁率の周波 数特性の測定結果である. 平坦なポリイミド表面に成膜さ れた $\mathrm{Zn}$ フェライト膜の低周波における複素比透磁率の実

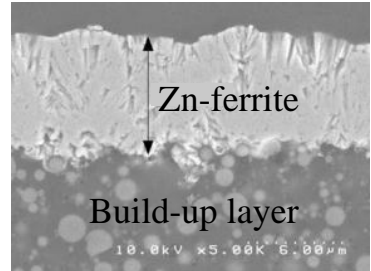

(a)

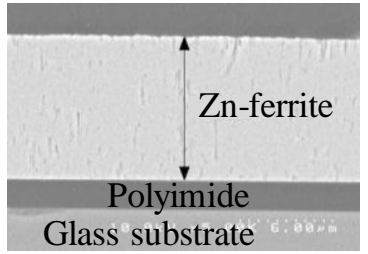

(b)
Fig. 4 Cross-sectional SEM image of the Zn-ferrite film, (a) deposited directly on the build-up layer of interposer substrate, polyimide/glass substrate.

(b) deposited on

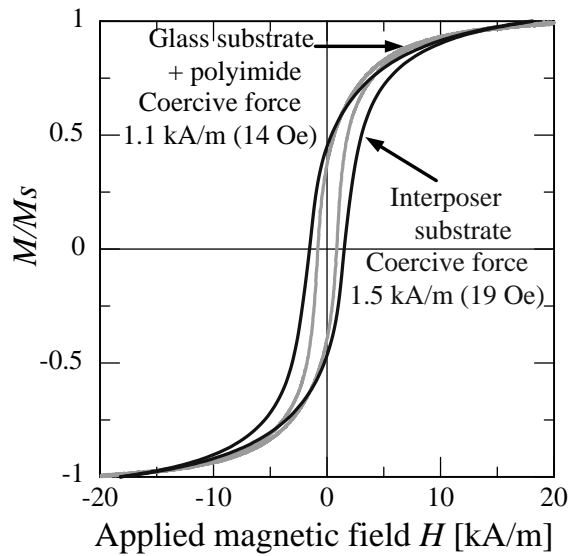

Fig. 5 Comparison of static magnetization curves measured in $\mathrm{Zn}$-ferrite films deposited on build-up layer of interposer substrate or polyimide/glass substrate.

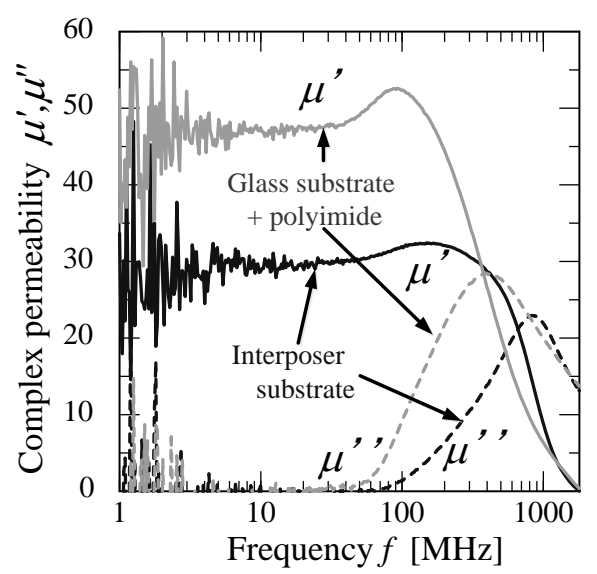

Fig. 6 Comparison of complex permeability vs. frequency curves measured in $\mathrm{Zn}$-ferrite films deposited on build-up layer of interposer substrate or polyimide/glass substrate.

部は約 50 であり,広帯域ノイズ吸収用として開発された同 一組成の Zn フェライトの透磁率の值とほぼ一致する 11)。

一方, 数 $\mu \mathrm{m}$ の凹凸があるビルドアップ層表面に成膜され た $\mathrm{Zn}$ フェライト膜の比透磁率は約 30 程度であり, 平坦な 下地に成膜した場合の 6 割程度まで低下している。

柱状結晶粒構造を有するスピンスプレー法フェライト膜 


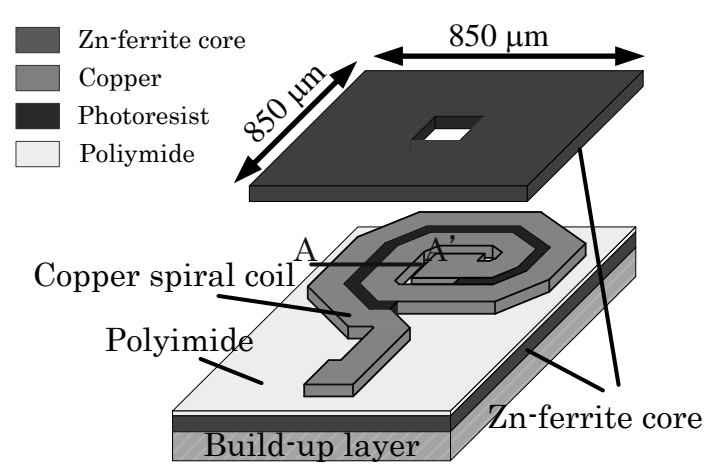

(a) Bird's eye view

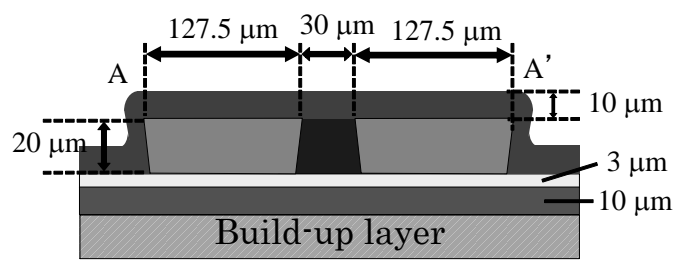

(b) Cross-section

Fig. 7 Schematic illustrations of $\mathrm{Zn}$-ferrite core planar power inductor embedded in interposer substrate.

は隣接柱状結晶粒間の強い磁気結合が軟磁性に寄与すると され 12)，表面凹凸の大きなビルドアップ層を下地にした場 合，不規則な方向の結晶成長によって磁気特性が劣化して いるものと推定される.

\section{4. 有機インターポーザヘのインダクタ内蔵と 電気特性の評価}

\section{1 有機インターポーザへのプレーナインダクタ内蔵}

有機インターポーザに内蔵した Zn フェライト磁心プレ 一ナインダクタの構造模式図を Fig. 7 に示す. サイズは $850 \mu \mathrm{m}$ 角である. スパイラルコイル端部の側壁にも Zn フ エライト膜を形成することで準閉磁路となる磁気回路構造 を採用している。下部 $\mathrm{Zn}$ フェライト膜の表面を平坦化す るために $3 \mu \mathrm{m}$ 厚ポリイミド層を形成し，電気メッキ法に より $20 \mu \mathrm{m}$ 厚の 2 ターン $\mathrm{Cu}$ スパイラルコイルを作製した. また，上部 Zn フェライト膜を作製する前にハードベーク フォトレジストによるコイル段差の平坦化を行った。 下部 $\mathrm{Zn}$ フェライト厚膜磁心の下地であるビルドアップ層の平 坦化を行っていないため, Fig. 6 に示したように, 磁心の 比透磁率は 30 程度に低下しているものと思われる. 比較の ために, 3 ターンの空心スパイラルインダクタを $\mathrm{Zn}$ フェラ イト磁心インダクタと同じ層に作製した。

Fig. 8 は有機インターポーザに内蔵した Zn フェライト 磁心スパイラルプレーナインダクタと空心スパイラルイン ダクタの上面写真（内蔵プロセスの途中で撮影）と断面写 真（内蔵プロセス終了後に撮影）を示したものである．同 図(b)に示したように, Zn フェライト厚膜の膜厚は目標の

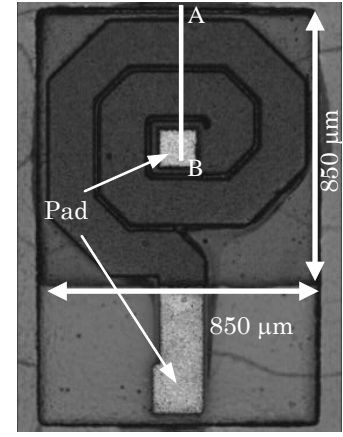

Zn-ferrite core, 2-turn spiral

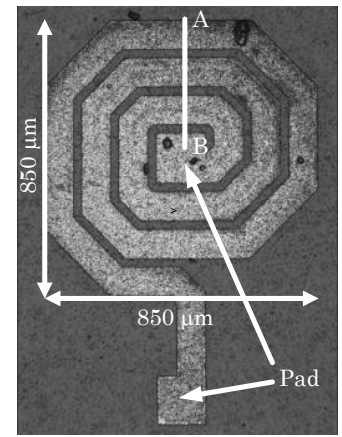

Air-core, 3-turn spiral (a) Top view

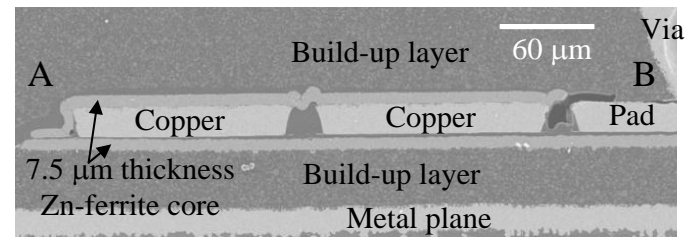

Zn-ferrite core, 2-turn spiral

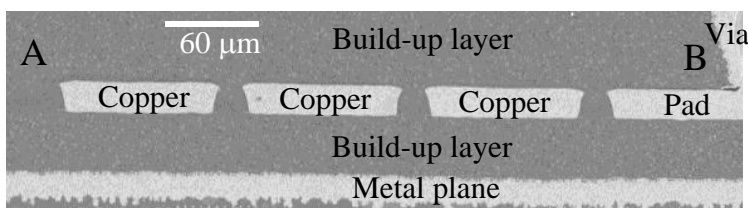

Air-core, 3-turn spiral

(b) Cross-section

Fig. 8 Top view and cross-section of embedded inductors in interposer substrate.

$10 \mu \mathrm{m}$ より薄い $7.5 \mu \mathrm{m}$ であった. また, 上部 $\mathrm{Zn}$ フェライ 卜厚膜磁心に対するコイル段差の平坦化が不十分なため, 特に，コイル導体スペーシングに凹凸が残存していること が分かる.

Zn フェライト厚膜の磁気特性劣化を抑えるための下地 ビルドアップ層表面の平坦化やプレーナインダクタ作製プ ロセスに幾つかの課題を残しているものの，インターポー ザ基板に磁性体インダクタを内蔵することに他に先駆けて 成功した。

\section{2 内蔵プレーナインダクタの電気特性}

インピーダンス/マテリアルアナライザ (Hewlett Packard：4291A)を用いて有機インターポーザ内蔵プレー ナインダクタの電気特性を測定した。測定にあたっては, 測定系やリード線の残留インピーダンスを補正するため に, Open/Short の校正を行っている．また，Fig. 8 の断面 写真を参考に,インダクタの直下約 $60 \mu \mathrm{m}$ の位置に $20 \mu \mathrm{m}$ 厚 $\mathrm{Cu}$ メタルプレーンを配した三次元電磁界解析モデルを 作製し, Fig. 6 の有機インターポーザに成膜した Zn フェラ イト厚膜磁心の複素比透磁率の実測值を用いて三次元有限 要素法電磁界解析ソフト（HFSS，(株)アンシス）により， インダクタンスならびに内部磁束密度分布を解析した。 


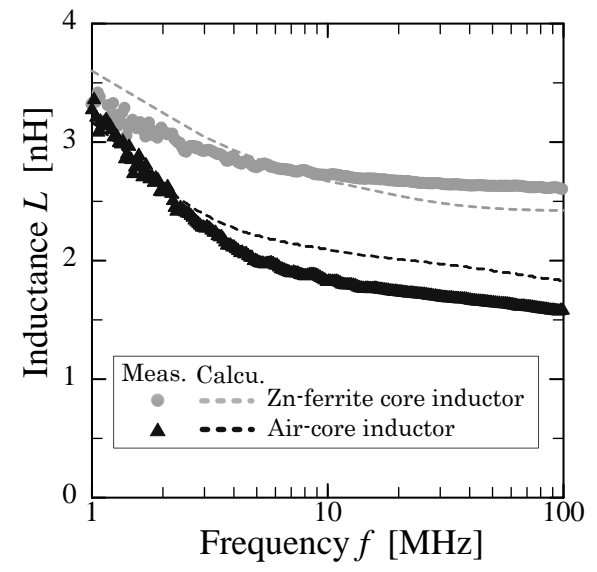

Fig. 9 Frequency characteristics of inductance measured in 2-turn spiral $\mathrm{Zn}$-ferrite core inductor and 3-turn spiral air core inductor. The calculated values are indicated using broken lines on the basis of 3-D electromagnetic field analysis (HFSS, Ansys Corp.).

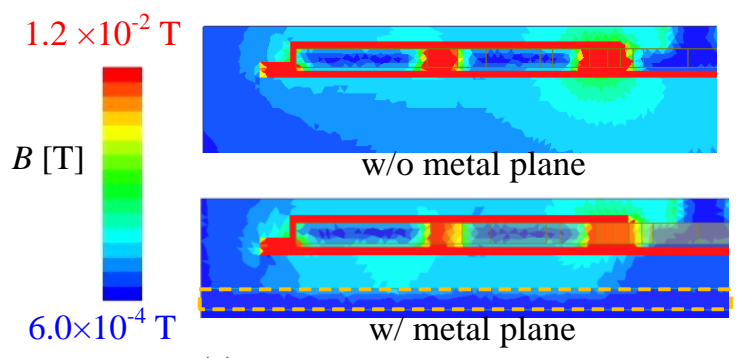

(a) 2-turn spiral Zn-ferrite core inductor

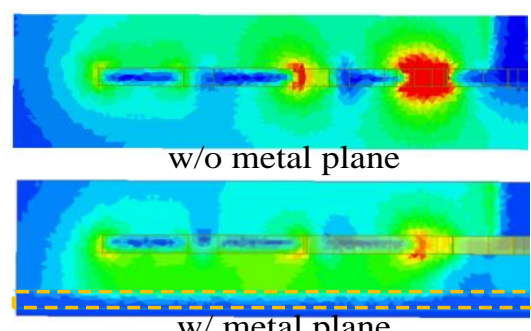

(b) 3-turn spiral air core inductor

Fig. 10 Magnetic flux density distribution of cross section view of each inductor with and without lower metal plane, which were calculated at $100 \mathrm{MHz}$ using 3-D electromagnetic field analysis (HFSS, Ansys Corp.).

Fig. 9 に内蔵インダクタのインダクタンスの周波数特性 の測定結果を示す。図中の破線は三次元電磁界解析による 計算值であり, 若干のずれはあるものの, 実測值の周波数 特性と概ね一致した. Zn フェライト磁心スパイラルインダ クタと空心スパイラルインダクタのインダクタンスは 1 $\mathrm{MHz}$ でほぼ同一の $3 \mathrm{nH}$ であった. 周波数が高くなるにつ れて, 空心インダクタのインダクタンスは大きく低下して おり, 周波数 $1 \mathrm{MHz}$ の值に比べて $100 \mathrm{MHz}$ では約半分に 低下した。一方, Zn フェライト磁心インダクタのインダク タンスの低下は $100 \mathrm{MHz}$ で約 $20 \%$ であった。

\section{5. 考 察}

Fig. 10 は, Zn フェライト磁心スパイラルプレーナイン ダクタと空心スパイラルインダクタの $100 \mathrm{MHz}$ における 磁束密度の断面分布の解析結果を示したものである. 図中 には，有機インターポーザへのインダクタ内蔵を模擬した $20 \mu \mathrm{m}$ 厚下層 $\mathrm{Cu}$ メタルプレーンを配置した場合と, インダ クタを自由空間に配置した場合の二通りの解析結果を示し てある。

Fig. 10 における Zn フェライト磁心プレーナインダクタ 内部の磁束密度分布から, 磁気シールド効果により磁心に

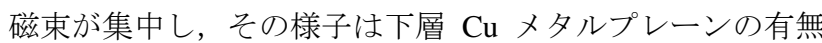
に大きく左右されないことが分かる，一方，空心インダク タから発生する磁束は周囲に大きく広がり，下層にメタル プレーンが存在する場合，スパイラルコイルの鎖交磁束量 が減少する. Fig. 9 における空心インダクタの高周波での顕 著なインダクタンスの低下は，下層メタルプレーンを貫く 高周波磁束によるうず電流によってコイル鎖交磁束が減少 していることが大きく影響しているものと考えられる.

近傍配線や回路のグランドパターンが三次元的に複雑に レイアウトされる LSI パッケージに空心インダクタを内蔵 する場合，高周波インダクタンスの低下に加えて，近傍配 線へのクロストークノイズの誘導も眯念されるため，イン ダクタのレイアウトに大きな制約を受ける.これに対して， コイルへの磁心装荷はインダクタ特性への近傍配線やグラ ンドパターンの影響を軽減するとともにクロストークノイ ズの抑制にも寄与するものと考えられる.

\section{6. まとめ}

複数の POL コンバータを同一パッケージに集積したパ ッケージレベル DC パワーグリッドの基盤技術の確立を目 的に， $100^{\circ} \mathrm{C}$ 以下の低温で合成が可能なスピンスプレー法 Zn フェライト磁心を用いて有機インターポーザへのプレ ーナインダクタ内蔵について検討を行った。得られた結果 を要約して以下に示寸.

(1) Zn フェライト磁心プレーナインダクタを有機インタ 一ポーザに内蔵する際の Zn フェライト厚膜の形成ならび に磁気特性の影響を調べた，有機インターポーザを構成す るガラスフィラーノエポキシ樹脂ビルドアップ層は数 $\mu \mathrm{m}$ 程度の表面凹凸を有し，スピンスプレー法で成膜される $\mathrm{Zn}$ フェライト厚膜は不規則に結晶粒が成長するため, 平坦な 面に成長させた $\mathrm{Zn}$ フェライト厚膜に比べて透磁率が 6 割 程度まで低下した。 今後, ビルドアップ層の平坦化プロセ スの導入が必要であると考えられる。

（2）空心インダクタと Zn フェライト厚膜磁心プレーナ インダクタを有機インターポーザに内蔵し, それぞれのイ ンダクタンスの周波数特性を測定した。空心インダクタの インダクタンスは周波数 $1 \mathrm{MHz}$ の值に比べて $100 \mathrm{MHz}$ で 
は約半分に低下し, Zn フェライト厚膜磁心インダクタの場 合のインダクタンスの低下は $100 \mathrm{MHz}$ で約 $20 \%$ であった.

(3) 有機インターポーザ内のインダクタ配置を模擬した 三次元高周波電磁界解析から, 空心インダクタの高周波で

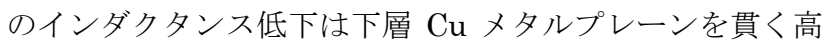
周波磁束によるうず電流が影響していることを明らかにし た。 また, 磁心を装荷することで近傍導体の影響を軽減で きることを示した。

以上の結果は，パッケージレベル DC パワーグリッドの 基盤技術としてのパッケージ内蔵パワーインダクタにおい て, 磁心の導入がインダクタサイズの縮小だけでなく、イ ンダクタ特性におよぼす近傍導体の影響やクロストークノ イズの軽減に必要不可欠であることを提示するものであ る、今後は, 磁気特性の劣化の少ない磁心作製プロセスの 検討と併せて, パワーインダクタ内蔵 LSI パッケージ集積 化電源の試作を行う予定である.

謝辞 本研究は平成 23 年度信州大学グリーンイノベーシ $\exists$ ヨ研究支援事業, 科学研究費補助金（課題番号; 24560328）の支援を得たことを記し，ここに感謝の意を表 します。

\section{References}

1) D. Gardner, G. Schrom, F. Paillet, B. Jamieson, T. Karnik, and Shekhar: IEEE Trans. Magn., 45, 4760 (2009).

2) R. Meere, N. Wang, T. O'Donnell, S.Kulkarni, S. Roy and S.C. O'Mathuna: IEEE Trans. Magn., 47, 4429 (2011).

3) S. Bae, Y. Hong, J Lee, J. Jalli, G. Abo, A. Lyle, B. Choi, and G Donohoe: IEEE Trans. Magn., 45, 4773 (2009).

4) P. Hazucha, G. Schrom, J. Halm, B. A. Bloechel, P. Hack, G.E. Dermer, S. Narendra, D. Gardner, T. Karnik, V. De, and S. Borkar: IEEE J.Solid-State Circuit, 40, 838 (2005).

5) K. Ishida, T. Yasufuku, S. Miyamoto, H. Nakai, M. Takamiya, T. Sakurai, and K. Takeuchi: IEEE J. Solid-State Circuit, 46, 1478 (2011).

6) M. Abe: J. Magn. Soc. Jpn., 22, 1125 (1998).

7) N. Matsushita, M. Abe, K. Kondo, S. Yoshida, T. Sato, and K. Okada: J. Surface Finishing Society Jpn., 61, 425 (2010).

8) S. Okazaki, A. Takeuchi, A. Takeshima, M. Sonehara, T. Sato, and N. Matsushita; IEEJ, 131, 484 (2011).

9) H. Ito, A. Takeuchi, S. Okazaki, H. Kobayashi, Y. Sugawa, A. Takeshima, M. Sonehara, N. Matsushita, and T. Sato: IEEE Trans. Magn., 47, 3204 (2011).

10) T. Sato: Magnetics Japan, 5, 475 (2010).

11) K. Kondo, H. One, S. Yoshida, N. Masuda, T. Harada: IEEJ, MAG-12-069, 59 (2012).

12) M. Abe: Magnetics Japan, 6, 66(2011).

2012 年 12 月 5 日受理, 2013 年 3 月 13 日再受理, 2013年3月 25 日採録 